\title{
Haematological indices, serum cholesterol and meat quality of broiler chickens fed diets with palm oil sludge substituting maize
}

\author{
G.E. Onibi ${ }^{1^{*}}$, A.O. Bobadoye ${ }^{2}$ and O.R. Folorunso ${ }^{3}$ \\ ${ }^{1}$ Department of Animal Production \& Health, School of Agriculture \& Agricultural Technology, \\ The Federal University of Technology, PMB 704, Akure, Ondo State, Nigeria. \\ ${ }^{2}$ Department of Forest Conservation and Protection, Forestry Research Institute of Nigeria, \\ Ibadan, Oyo State, Nigeria. \\ ${ }^{3}$ Department of Animal Production, Federal College of Agriculture, Akure, Ondo State, \\ Nigeria. \\ *Corresponding author: gbengaonibi@yahoo.com; Phone +234-8033503320 \\ ABSTRACT
}

\begin{abstract}
A 49-day feeding trial was conducted to assess the effect of substituting $10,20,30$ and $40 \%$ of energy supplied by maize in a control diet with energy from palm oil sludge (POS) using 200 Shaver Starbo chickens allotted at 10 birds per replicate and 4 replicates per treatment. On the $49^{\text {th }}$ day, four female birds per replicate were humanely slaughtered for haematological variables, serum cholesterol and oxidative stability of refrigerated meat. Substituting maize with POS increased dietary ether extract. Haematological variables were not significantly $(P>0.05)$ influenced by dietary treatment. Serum cholesterol contents increased from $140.32 \pm 5.88$ in the control to $198.00 \pm 1.58 \mathrm{mg} / \mathrm{dl}(\mathrm{P}<0.05)$ at $40 \%$ substitution $(41.11 \%$ increase $)$. Lipid contents of the meat increased with increasing levels of POS in the diets $(P<0.05)$. Thigh, drumstick and breast muscle lipid contents were $119.9 \pm 9.8,103.1 \pm 6.4$ and $91.6 \pm 7.1 \mathrm{~g} / \mathrm{kg}$ muscle, respectively $(\mathrm{P}<0.05)$. Oxidative deterioration of the meat, measured as malondialdehyde (MDA) concentration was lowest for meat from chickens fed the control diet and increased with increasing levels of dietary POS $(P<0.05)$. It was concluded that even if economic returns by partial substitution of maize with POS is enhanced, the effect on meat quality in terms of elevated lipids, cholesterol and oxidative susceptibility vis-à-vis accumulation of dangerous lipid peroxidation products in/of the meat are of human health concern.
\end{abstract}

\section{INTRODUCTION}

Keywords: Broilers, palm oil sludge, haematology, cholesterol, oxidative stability.

Several approaches are adopted to guarantee food security for people worldwide. This problem of malnutrition is more pronounced in less developed nations (FAO, 2008) and this has always led to resurgence of interest in the sourcing of inexpensive alternative feed ingredients as replacement for the more expensive conventional ones in animal feed formulation. The import of this is to increase the availability and affordability of animal products in order to alleviate global food crisis. The alternative feed ingredients also referred to as non-conventional feedstuffs are mostly agro-industrial by-products. The importance of agro-industrial by-products and the socalled "wastes" in meeting the energy and protein needs of farm animals is best appreciated when it is realised that feeding alone accounts for about 60 to $80 \%$ of the cost of intensively reared monogastic animals (Fetuga, 1977).
Cereals constitute the major energy feedstuff and also make up more than one third of the finished feed for poultry. Maize is an important source of energy in human nutrition and due to its high prices, it is becoming more expensive to use at high levels in poultry feeds. Therefore, a by-product of interest in palm oil production in term of substituting energy in conventional pigs and poultry diet is palm oil sludge (POS). Palm oil sludge is the material that remains after decanting the palm oil mill effluent and can cause problem to the entire surrounding ecosystem. It has a crude protein (CP) of $96 \mathrm{~g} / \mathrm{kg}$ and metabolisable energy (ME) of $17.76 \mathrm{MJ} / \mathrm{kg}$ (Devendra, 1977). This makes it relatively comparable to maize with $90 \mathrm{~g} / \mathrm{kg} \mathrm{CP}$ and 14.37 $\mathrm{MJ} / \mathrm{kg}$.

Poultry production, especially broilers, provides the opportunity of meeting animal protein needs of humans from livestock industry. In Nigeria for 
example, poultry meat has wide acceptance as it lacks traditional and religious taboos in contrast to pork, which is rejected by Muslims. Bobadoye et al. (2006) reported improved growth performance of broilers at up to $40 \%$ energy for energy substitution of POS for maize (160 g/kg dietary inclusion of POS). Hertrampt (1988) also showed that POS in place of maize at a level of 15 to $30 \%$ increased the daily feed intake and the average daily weight gain of pigs in addition to a significant reduction in feed cost. Thus, POS, which is relatively uneconomical to humans, could be an alternative to maize in livestock diets.

Haematological parameters have been used as indicators of the health status of animals (Awotwi, 1990; Aletor and Egberongbe, 1992; Babatunde et al., 1992) and there exists a positive relationship between cholesterol and coronary heart diseases in humans (Yourtotalhealth, 2008). Therefore, the need to meet consumer expectations in relation to quality of meat, owing to dietary incorporation of POS deserve due consideration. These necessitated this study which was aimed at assessing the haematological variables, serum cholesterol concentration, muscle fat content and oxidative state of refrigerated meat of broiler chickens fed diets with up to $40 \%$ energy from maize replaced with energy supplied by palm oil sludge.

\section{MATERIALS AND METHODS}

The experiment was conducted at the Teaching and Research Farm of the Federal University of Technology Akure, Ondo State (latitude $7^{\circ} 15^{\prime} \mathrm{N}$ and longitude $5^{\circ} 12^{\prime} E$ ) in the humid zone of SouthWestern Nigeria. It is an agrarian community with many oil palm plantations as well as species of tropical hardwoods, including mahogany, iroko, and obeche.

The POS used for the experiment was collected from the Oil Palm Processing Unit of the Federal College of Agriculture, Akure, Nigeria. The study involved the use of five diets and the gross composition is shown in Table 1. The control diet (Diet 1) contained maize as the main energy source. The energy supplied by maize in the control diet was replaced at 10, 20, 30 and $40 \%$ by that of POS in Diets 2, 3, 4 and 5 , respectively. Each of the diets without POS inclusion was milled weekly at the University's Feedmill. These basal diets were hand-mixed with POS every other day to keep them as fresh as possible.

The experimental design was completely randomized and the birds were reared on deep litter. Two hundred (200) day-old chicks (Shaver Starbo breed) were used for the experiment. There were four replicates per dietary treatment and each replicate had 10 birds (5 males and 5 females). After a preexperimental brooding period of one-week, the birds were placed on the starter diets for three weeks and thereafter on finisher diets for four weeks. Feed and water were given ad-libitum. The birds were maintained under similar managerial and hygienic conditions and the handling protocol was in accordance with that of the University's Ethical Committee on Care of Experimental Animals.

At the end of the feeding trial, four female birds per replicate (16 birds/treatment) were selected and bled via wing veins using sterile $21 \mathrm{G} \times 1 \frac{1}{2} 2^{\prime \prime}(0.8 \times 40 \mathrm{~mm})$ needles and syringes into bijou bottles containing anticoagulant (ethylene diamine tetra acetic acid; EDTA) for determination of haematological variables as described by Lamb (1981). Blood samples for serum cholesterol were collected into $10 \mathrm{ml}$ test tubes without anticoagulant for serum separation. Decanted sera from the coagulated blood samples were saved by freezing at $-18^{\circ} \mathrm{C}$ until analysed for total cholesterol according to Feng et al. (1973). Birds were electrically stunned ( $35 \mathrm{~V}$ and $75 \mathrm{~mA}$ electric stun), slaughtered by cutting the jugular vein, bled and scalded. After manual de-feathering and evisceration, the chicken carcasses were chilled at $4^{\circ} \mathrm{C}$ for 3 hours. Thereafter, the breast, drumstick and thigh muscles from the left side of the carcasses were de-skinned, deboned and divided into two parts. One part was frozen at $-18^{\circ} \mathrm{C}$ and the other part was refrigerated at $4^{\circ} \mathrm{C}$ for 6 days prior to frozen storage at $-18^{\circ} \mathrm{C}$. Evaluation for oxidative stability was conducted using the aqueous extraction 2-

thiobarbituric acid (TBA) method (Pikul et al., 1989) within two weeks of frozen storage. The moisture and lipid contents of the selected muscle parts were determined using AOAC (1995) methods.

The data collected were subjected to one-way analysis of variance (for haematological variables and serum cholesterol contents) and $5 \times 3$ factorial analysis (for moisture, lipids and oxidative stability of muscles). Where significant differences were found, the means were compared using Duncan's New Multiple Range Test (DNMRT). The Minitab Statistic Package (v.10.2, Minitab Inc. USA) was used for the analysis. 
Agric. Biol. J. N. Am., 2011, 2(3): 552-558

Table 1: Gross composition of experimental diets ( $/ \mathrm{kg})$

\begin{tabular}{|c|c|c|c|c|c|c|}
\hline \multirow[t]{3}{*}{ Ingredients } & & \multicolumn{5}{|c|}{ Diets } \\
\hline & & 1 & 2 & 3 & 4 & 5 \\
\hline & $\begin{array}{l}\% \text { maize energy } \\
\text { replaced with POS }\end{array}$ & 0 & 10 & 20 & 30 & 40 \\
\hline & & \multicolumn{5}{|c|}{ Broiler starters } \\
\hline \multicolumn{2}{|l|}{ Maize } & 560.0 & 504.0 & 448.0 & 392.0 & 336.0 \\
\hline \multicolumn{2}{|c|}{ Palm oil sludge } & - & 45.3 & 90.6 & 135.9 & 181.2 \\
\hline \multicolumn{2}{|l|}{ Maize offal } & - & 5.0 & 5.0 & 5.0 & 5.0 \\
\hline \multicolumn{2}{|c|}{ Soyabean meal } & 160.0 & 140.0 & 135.0 & 120.0 & 105.0 \\
\hline \multicolumn{2}{|c|}{ Groundnut cake } & 153.5 & 144.5 & 144.0 & 135.3 & 136.3 \\
\hline \multicolumn{2}{|c|}{ Brewers dried grain } & 40.0 & 74.7 & 90.0 & 125.3 & 150.0 \\
\hline \multicolumn{2}{|c|}{ Basal ingredients $^{1}$} & 86.5 & 86.5 & 86.5 & 86.5 & 86.5 \\
\hline \multicolumn{2}{|l|}{ Total } & 1000.0 & 1000.0 & 1000.0 & 1000.0 & 1000.0 \\
\hline \multicolumn{7}{|c|}{ Calculated composition } \\
\hline \multicolumn{2}{|c|}{ Crude protein $(\mathrm{g} / \mathrm{kg})$} & 224.3 & 223.6 & 223.7 & 225.3 & 223.2 \\
\hline \multicolumn{2}{|c|}{$\mathrm{ME}(\mathrm{Kcal} / \mathrm{kg})$} & 2982.48 & 2987.27 & 2994.10 & 3003.14 & 3016.17 \\
\hline \multicolumn{2}{|c|}{ Ether extract $(\mathrm{g} / \mathrm{kg})$} & 42.2 & 50.2 & 58.4 & 67.2 & 75.2 \\
\hline & \multicolumn{5}{|c|}{ Broiler finishers } \\
\hline \multicolumn{2}{|l|}{ Maize } & 500.0 & 450.0 & 400.0 & 350.0 & 300.0 \\
\hline \multicolumn{2}{|c|}{ Palm oil sludge } & - & 40.4 & 80.8 & 121.2 & 161.6 \\
\hline \multicolumn{2}{|c|}{ Brewers dried grain } & 53.0 & 62.6 & 72.2 & 81.8 & 91.4 \\
\hline \multicolumn{2}{|c|}{ Basal ingredients $^{2}$} & 447.0 & 447.0 & 447.0 & 447.0 & 447.0 \\
\hline \multirow{2}{*}{\multicolumn{2}{|c|}{$\begin{array}{l}\text { Total } \\
\text { Calculated composition }\end{array}$}} & 1000.0 & 1000.0 & 1000.0 & 1000.0 & 1000.0 \\
\hline & & & & & & \\
\hline \multicolumn{2}{|c|}{ Crude protein $(\mathrm{g} / \mathrm{kg})$} & 197.1 & 193.3 & 194.4 & 195.4 & 196.6 \\
\hline \multicolumn{2}{|c|}{$\mathrm{ME}(\mathrm{Kcal} / \mathrm{kg})$} & 2916.86 & 2936.70 & 2955.55 & 2974.38 & 2998.23 \\
\hline \multicolumn{2}{|c|}{ Ether extract $(\mathrm{a} / \mathrm{kg})$} & 52.0 & 59.0 & 66.3 & 73.5 & 80.7 \\
\hline
\end{tabular}

$\mathrm{ME}=$ Metabolisable energy

POS = Palm oil sludge; contained moisture, 250; crude protein, 89; ether extract, 260 and crude fibre, $80 \mathrm{~g} / \mathrm{kg} . \mathrm{ME}=4,245 \mathrm{Kcal} / \mathrm{kg}$ (Devendra, 1977).

${ }^{1}$ Broiler starter basal diet contained fish meal, 50; bone meal, 25; starter premix, 2.5; methionine, 2.5 ; lysine, 1.5 and salt, 5.0 g/kg.

${ }^{2}$ Broiler finisher basal diet contained maize offal, 132.5; soyabean meal, 130; groundnut cake, 130; fish meal, 12; bone meal, 25; oyster shell, 5.0; finisher premix, 2.5; methionine, 2.5; lysine, 1.5 and salt, $5.0 \mathrm{~g} / \mathrm{kg}$.

\section{RESULTS AND DISCUSSION}

The ether extract contents of the diets (Table 1) sequentially increased with increasing dietary levels of POS with between 0.80 and $0.88 \%$ for starter diets, and 0.70 and $0.72 \%$ for finisher diets.

The results of haematological variables of the broiler chickens are shown in Table 2. None of the haematological parameters measured were significantly $\quad(P>0.05)$ influenced by dietary treatments. Also, no consistent trend in relation to dietary treatments could be established. Previous reports by Aletor et al. (1989) and Aletor and Egberongbe (1992) showed that blood variables that are most commonly affected by dietary treatments include packed cell volume (PCV) and red blood cell (RBC). Brown and Clime (1972) reported that decreased RBC is usually associated with low quality feed and protein deficiency. However, in this study, these parameters as well as those of other erythrocytic (haemoglobin concentration, mean corpuscular volume, mean corpuscular haemoglobin, mean corpuscular haemoglobin concentration and erythrocyte sedimentation rate) and differential leukocytic (heterophils, eosinophils, basophils, lymphocytes and monocytes) values were not affected, suggesting similar influence of diets on the blood parameters. The haematological values were generally comparable to those quoted for domestic and commercial chickens in Nigeria (Oyewale, 1987) and Ghana (Awotwi, 1990).

The serum cholesterol contents of the chickens (Table 3) significantly $(P<0.05)$ increased with increasing levels of POS in the diets. Compared with chickens offered the control diet, the percentage 
increases in serum cholesterol contents were 7.34 , $13.04,34.20$ and 41.11 for chickens fed Diets 2, 3, 4 and 5 , respectively. This suggests that POS inclusion in the diets could lead to hypercholesterolmanic tendency in birds.

Table 2: Haematological variables of broiler chickens fed diets containing palm oil sludge in partial replacement for maize

\begin{tabular}{|c|c|c|c|c|c|}
\hline \multirow[t]{2}{*}{ Parameters } & \multicolumn{5}{|c|}{ Diets } \\
\hline & 1 & 2 & 3 & 4 & 5 \\
\hline \multicolumn{6}{|l|}{ Erythrocytic values } \\
\hline Packed cell volume (\%) & $29.00 \pm 1.73$ & $27.00 \pm 1.25$ & $27.31 \pm 1.08$ & $26.67 \pm 1.16$ & $27.33 \pm 1.16$ \\
\hline Red blood cell $\left(\times 10^{6} / \mathrm{mm}^{3}\right)$ & $3.07 \pm 0.31$ & $3.00 \pm 0.10$ & $2.95 \pm 0.64$ & $2.92 \pm 0.09$ & $3.14 \pm 0.38$ \\
\hline Mean corpuscular volume $\left(\mu \mathrm{m}^{3}\right)$ & $105.70 \pm 3.91$ & $105.13 \pm 4.65$ & $104.92 \pm 7.88$ & $106.99 \pm 6.90$ & $102.66 \pm 7.57$ \\
\hline Mean corpuscular haemoglobin $(\mathrm{pg})$ & $32.65 \pm 1.20$ & $33.09 \pm 0.74$ & $33.66 \pm 3.10$ & $33.67 \pm 3.00$ & $33.08 \pm 3.98$ \\
\hline Mean corpuscular haemoglobin conc. (\%) & $34.87 \pm 0.82$ & $33.98 \pm 0.96$ & $33.95 \pm 0.49$ & $33.85 \pm 0.82$ & $33.85 \pm 0.62$ \\
\hline Erythrocyte sedimentation rate $(\mathrm{mm} / \mathrm{hr})$ & $3.33 \pm 1.16$ & $4.00 \pm 0.50$ & $3.67 \pm 0.29$ & $4.17 \pm 0.29$ & $4.17 \pm 0.29$ \\
\hline \multicolumn{6}{|l|}{ Differential leukocytic values (\%) } \\
\hline Lymphocytes & $49.67 \pm 0.58$ & $53.67 \pm 4.04$ & $54.00 \pm 1.73$ & $54.67 \pm 0.58$ & $53.00 \pm 2.65$ \\
\hline Monocytes & $10.33 \pm 1.53$ & $8.33 \pm 1.53$ & $9.00 \pm 1.73$ & $8.67 \pm 2.52$ & $9.67 \pm 2.08$ \\
\hline
\end{tabular}

Mean \pm SD

No two means within the same row are significant $(P>0.05)$

POS $=$ Palm oil sludge.

Table 3: Serum cholesterol of broiler chickens fed diets containing palm oil sludge in partial replacement for maize

\begin{tabular}{|l|c|c|c|}
\hline Diets & $\begin{array}{c}\text { \% Maize energy replaced } \\
\text { with POS }\end{array}$ & $\begin{array}{c}\text { Serum cholesterol contents } \\
(\mathrm{mg} / \mathrm{dl})\end{array}$ & $\begin{array}{c}\text { \% increase in serum cholesterol contents } \\
\text { compared with Diet 1 }\end{array}$ \\
\hline 1 & 0 & $140.32 \pm 5.88^{\mathrm{a}}$ & 7.34 \\
\hline 2 & 10 & $150.62 \pm 6.45^{\mathrm{b}}$ & 13.04 \\
\hline 3 & 20 & $158.62 \pm 6.50^{\mathrm{b}}$ & 34.20 \\
\hline 4 & 30 & $187.91 \pm 6.01^{\mathrm{c}}$ & 41.11 \\
\hline
\end{tabular}

POS = Palm oil sludge

Mean $\pm S D$

Means for serum cholesterol contents having different superscripts are significant $(P<0.05)$

Table 4 shows the moisture and lipid contents of meat of the experimental chickens. The moisture contents was not significantly $(P>0.05)$ influenced by the experimental diets. However, there was a significant $(P<0.001)$ effect of the muscle type with drumstick having the highest moisture content followed by thigh and least for breast muscle. The moisture contents obtained in the study were similar to those reported for Silvas broiler chickens (Onibi, 2006). There was a significant $(P<0.05)$ increase in the lipid contents of the muscles with increasing levels of POS in the diets. This suggests that POS would promote fat deposition in broiler chickens. The muscle type was also significantly $(P<0.05)$ influenced with the thigh muscle having the highest lipid content followed by drumstick and least for breast muscle. This agrees with earlier study that fat deposition is higher in thigh than drumstick and lowest for breast muscles (Onibi, 2006). 
Table 4: Moisture and lipid contents of meat ( $\mathrm{g} / \mathrm{kg}$ muscle) from broiler chickens fed diets containing palm oil sludge

\begin{tabular}{|c|c|c|c|c|c|}
\hline Diets & \multicolumn{2}{|c|}{$\begin{array}{l}\% \text { Maize energy } \\
\text { replaced by POS }\end{array}$} & Muscle type & Moisture & Lipids \\
\hline \multirow{3}{*}{1} & 0 & 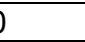 & Breast & $628.3 \pm 17.6$ & $88.3 \pm 11.0$ \\
\hline & & & Drumstick & $730.0 \pm 10.0$ & $97.3 \pm 1.0$ \\
\hline & & & Thigh & $651.7 \pm 7.6$ & $111.3 \pm 2.5$ \\
\hline \multirow{3}{*}{2} & & & & & ח0 \\
\hline & & 10 & Drumstick & $\frac{681.5 \pm 2.5}{690.0 \pm 2.5}$ & $\begin{array}{l}88.1 \pm 3.8 \\
9.79 \pm 2.0\end{array}$ \\
\hline & & & Thigh & $698.3 \pm 7.6$ & $112.4 \pm 7.8$ \\
\hline \multirow{3}{*}{3} & & 20 & Breast & $6517+176$ & $897+98$ \\
\hline & & & Drumstick & $633.3 \pm 40.4$ & $105.8 \pm 10.3$ \\
\hline & & & Thigh & $696.7 \pm 25.7$ & $116.2 \pm 9.3$ \\
\hline \multirow[t]{3}{*}{4} & & 30 & Breast & $668.3 \pm 17.6$ & $96.1+36$ \\
\hline & & & Drumstick & $700.0 \pm 20.0$ & $106.2 \pm 3.4$ \\
\hline & & & Thigh & $670.0 \pm 10.0$ & $128.5 \pm 1.8$ \\
\hline \multirow[t]{3}{*}{5} & & 10 & Breast & $667.5 \pm 12.5$ & $95.2 \pm 5.2$ \\
\hline & & & Drumstick & $673.3 \pm 22.5$ & $108.1 \pm 2.3$ \\
\hline & & & Thigh & $660.0 \pm 15.0$ & $131.1 \pm 2.6$ \\
\hline \multicolumn{6}{|c|}{ Statistical significance } \\
\hline Diet & & & & NS & *** \\
\hline \multicolumn{2}{|c|}{ Muscle type } & & & 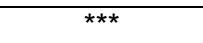 & *** \\
\hline \multicolumn{2}{|c|}{ Diet $x$ Muscle type } & & & $\star \star \star \star *$ & NS \\
\hline \multicolumn{6}{|c|}{ Mean separation } \\
\hline \multicolumn{6}{|c|}{ Dietary effect } \\
\hline 1 & & & & $670.0 \pm 47.4$ & $99.0 \pm 11.5$ \\
\hline 2 & & & & $691.9 \pm 14.0$ & $99.7 \pm 11.3(\mathbf{0 . 7 1})$ \\
\hline 3 & & & & $677.2 \pm 32.4$ & $103.9 \pm 14.7(4.95)$ \\
\hline 4 & & & & $673.3 \pm 22.5$ & $110.3 \pm 14.6$ (11.41) \\
\hline 5 & & & & $666.9 \pm 16.0$ & $111.5 \pm 16.1$ (12.63) \\
\hline \multicolumn{6}{|c|}{ Muscle type effect } \\
\hline Breast & & & & $660.7 \pm 24.0^{a}$ & $91.6 \pm 7.1^{\mathrm{a}}$ \\
\hline Drumstick & & & & $695.3 \pm 29.5^{b}$ & $103.1 \pm 6.4^{\mathrm{b}}$ \\
\hline Thigh & & & & $675.3 \pm 23.3^{a}$ & $119.9 \pm 9.8^{c}$ \\
\hline
\end{tabular}

POS $=$ Palm oil sludge

Mean $\pm S D, N S=$ Not significant $(P>0.05),{ }^{* * *}=P<0.001$

Figures in parenthesis are for percent increase compared to feeding Diet 1.

Means with different superscripts within the same column and for the same parameter are significant $(P<0.05)$

Table 5 shows the results of the extent of oxidation, measured as the concentration of malondialdehyde (MDA) in meat during refrigeration storage. There were significant differences $(P<0.001)$ due to the diet and muscle type at days 1 and 6 of refrigerated storage. Interaction of the diet and muscle type is not significant $(P>0.05)$. The MDA concentration of meat increased with increasing levels of POS and also with increasing length of storage, irrespective of muscle type. The increase in MDA concentration with increasing length of storage agrees with Onibi et al. (1998) and Onibi (2006) that deteriorative changes due to oxidation continue to occur in refrigerated meat. The significant effect of the diet on MDA concentration for at days 1 and 6 may be ascribed to the increase in lipid contents of the meat. The ether extract of the diets (Table 1) and lipid contents of meat from broiler chickens (Table 4) increased with increasing dietary POS. Thus, this result agrees with Lin et al. (1989) and Onibi (2006) that the higher the quantity of lipids in meat, the higher the susceptibility of such meat to lipid oxidation. Similarly, the MDA concentration of the thigh was the highest at both days 1 and 6 , followed by drumstick and lowest for the breast muscle. This trend showed that the thigh muscle which had higher fat content than the drumstick (Table 4) was more susceptible to oxidation. Thus, the susceptibility of chicken parts to oxidation differed significantly from one another and it agrees with earlier studies (Monahan et al., 1992; 
Onibi, 2006; Onibi et al., 2009) that higher quantity of lipids in meats led to higher peroxidative changes. Table 5: Oxidative stability of refrigerated meat (mg MDA/kg muscle) from broiler chickens fed diets containing palm oil sludge

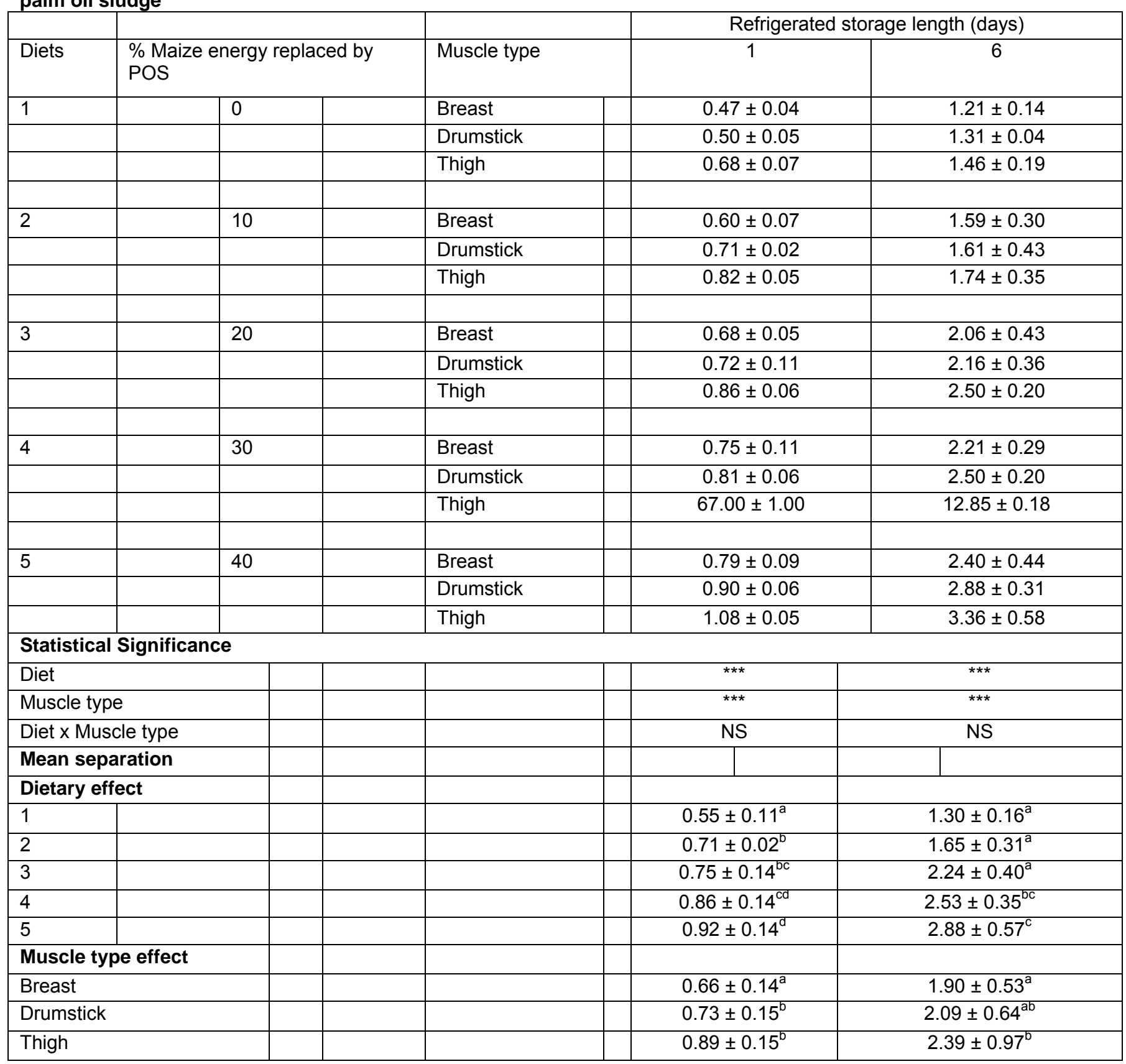

POS = Palm oil sludge

Mean \pm SD, NS $=$ Not significant $(P>0.05),{ }^{* * *}=P<0.001$

Means with different superscripts within the same column and for the same parameter are significant $(\mathrm{P}<0.05)$.

\section{CONCLUSIONS:}

The replacement of maize with POS in diets of broiler chickens at up to $40 \%$ energy for energy substitution (180 and $160 \mathrm{~g} / \mathrm{kg}$ dietary inclusion of POS in starter and finisher diets) increased dietary ether extract by up to 78 and $55 \%$ (starter and finisher diets respectively) and lipid contents of the meat by as much as $13 \%$. Erythrocytic and leukocytic values were not influenced by POS inclusion but the serum cholesterol content was increased by up to $41 \%$. Similarly, POS inclusion in diets increased the 
oxidation of meat during refrigerated storage. Although, Bobadoye et al. (2006) reported better economic returns by partial substitution of maize with POS, the effect on meat quality in terms of elevated lipids, cholesterol and oxidative susceptibility vis-à-vis accumulation of dangerous lipid peroxidation products in/of the meat are of human health concern.

\section{ACKNOWLEDGMENT:}

The authors are grateful to Mr. M.O. Oguntokun, Prince J.A. Adesida, Mrs B. Usifo and Mrs G.T. Osho for technical assistance during laboratory analyses.

\section{REFERENCES}

Aletor, V.A. and Egberongbe, O. (1992). Feeding differently processes soyabeans. Part 2: An assessment of haematological responses in the chickens. Die Nahrung 36(4): 364-369.

Aletor, V.A., Agbede, J.O. and Sobondo, R.A. (1989). Heamatological and biological aspect of feeding broiler chicken conventional or underutilised protein resources. Proceeding of Silver Anniversary Conference of Nigerian Society for Animal Production and Inaugural Conference of World Poultry Science Association, Gateway Hotel, Abeokuta, Nigeria, 21-26 March, 1989, Paper No. 79.

AOAC (1995). Official Methods of Analysis. Association of Official Analytical Chemists. $16^{\text {th }}$ ed. Washington D.C.

Awotwi, E.K. (1990). A Study Of Baseline Haematological Values of Domestic And Commercial chickens in Ghana. Bulletin of Animal Health and Production in Africa 38: 453-458.

Babatunde, G.M., Fajimi, A.O. and Oyejide, A.O. (1992). Rubber Seed Oil Versus palm oil in broiler chicken diets. Effects on performance, nutrient digestibility, haematology and carcass characteristics. Animal Feed Science and Technolology 35: 133-146.

Bobadoye, A.O., Onibi, G.E. and Fajemisin, A.N. (2006). Performance Characteristics and muscle fat contents of broiler finishers fed diets containing palm oil sludge as a partial replacement for maize. Journal of Agriculture, Forestry and the Social Sciences 4(2): 162-169.

Brown, J.A. and Clime, T.R. (1972). Nutrition and haematological values. Journal of Animal Science 35: 211-218.

Devendra, C. (1977). Utilization of feeding stuff from oil palm. Proc. National Workshop on Oil Palm ByProduct Utilization. $14^{\text {th }}-15^{\text {th }}$ December, 1977. Kuala Lumpur. pp $131-166$.
FAO (2008). Food and Agriculture Organisation of the United Nations. Prevalence of undernourishment in total population. Food Security Statistics. http://www.fao.org/faostat/foodsecurity/index en.htm, Accessed on 24 December, 2008.

Feng, H., Pi, C., Wang, R. and Chen, L. (1973). Use of ferric ammonium sulphate in serum cholesterol determination. Clinical Chemistry 19(1): 121-122.

Fetuga, B. L. (1977). Animal production in Nigeria and feed supplies. Nigerian Journal of Animal Production 4: 1941.

Hertrampt, J. (1988). Unconventional feedstuff for livestock. Muhle Mishfulter Chnik 125(9): 103-109.

Lamb, G. N. (1981). Manual of Veterinary Laboratory Techniques. CIBA-Geirgy, Kenya Pp 92-109.

Lin, C.F., Gray, J.I., Asghar, A. Buckley, D.J., Booren, A.M. and Flegal, C.J (1989). Effect of dietary oils and $\alpha$ tocopherol supplementation on lipid composition and stability of broiler meat. Journal of Food Science 54(6): 1457-1460, 1484.

Monahan, F.J., Gray, J.I., Booren, A.M., Miller, E.R., Buckley, D.J., Morrissey, P.A. and Goma, E.A. (1992). Influence of dietary treatment on lipid and cholesterol oxidation in pork. Journal of Agriculture and Food Chemistry 40: 1310-1315.

Onibi, G.E. (2006). Dietary oil quality and vitamin E supplementation. II: effect on carcass and meat quality of broiler chickens. Bowen Journal of Agriculture 3(1): $106-115$

Onibi, G.E., Adebisi, O.E., Fajemisin, A.N. and Adetunji, A.V. (2009). Response of broiler chickens in terms of performance and meat quality to garlic (Allium sativum) supplementation. African Journal of Agricultural Research 4(5): 511-517.

Onibi, G.E., Scaife,J.R., Murray, I. and Fowler, V.R. (1998). Use of a-tocopherol acetate to improve fresh pig meat quality of full- fat rapeseed-fed pigs. Journal of American Oil Chemists' Society 75: 189-198.

Oyewale, J.O. (1987). Haematological studies on apparently healthy Nigerian domestic chickens (Gallus domesticus). Bulletin of Animal Health and Production in Africa 35: 108-112.

Pikul, L.J., Leszeezynsk, D.E and Kummerow, F.A. (1989). Evaluation of three modified TBA methods for measuring lipid oxidation in chicken meat. Journal of Agriculture and Food Chemistry 37: 1309-1313.

Yourtotalhealth (2008). cholesterol centre. http://www.yourtotalhealth.ivillage.com/cholesterol. Accessed on 22 December, 2008. 